\author{
Meirbaev B.B., "Zhorabek Zh. \\ Al-Farabi Kazakh national university, Kazakhstan, Almaty \\ *e-mail: 00077-94@mail.ru
}

\title{
RELIGION AND POLITICS IN THE ISLAMIC WORLD
}

The main platform that unites the Islamic countries of the world on a religious basis is Islam. Often talk about the importance of Islamic values for the Muslim world, in order to cultivate the spiritual culture and socio-political life of Muslim countries. Secular and religiously oriented politicians, who revived the tradition of the early Islamic, showed that the only way for the Arab world is to follow the Muslim way of life. Among these concepts of Islamic sociology, the Islamic economy and the Islamic state, it is assumed that traditional Islamic values will correspond to the current state of the country and modernize the political and socio-economic situation. That is, this article is a systematic analysis taking into account the real situation when studying the relationship between religion and the state in the modern Islamic world.

Key words: Islam, politics, religion, state, relationship.

$$
\begin{gathered}
\text { Мейрбаев Б.Б., “Жорабек Ж. } \\
\text { Ә^-Фараби атындағы Қазақ, ұлттық, университеті, Қазақстан, Алматы қ. } \\
\text { "e-mail: 00077-94@mail.ru }
\end{gathered}
$$

\section{Қазіргі ислам әлеміндегі дін және саясат}

Ислам әлемі елдерін діни негізде біріктіретін негізгі тұғыр, бұл - ислам діні. Әлем мұсылмандарын мәдени өрлеуі мен идеялық ұйысуының жолдарын іздеуде мұсылман ойшылдары мұсылмандық шығыс елдерінің рухани мәдениеті мен қоғамдық саяси өмірін дамыту үшін ислам құндылықтарының маңызы туралы жиі айтыла бастады. Ертедегі ислами мемлекеттілік дәстүрін қайта көтерген зайырлы және Аіни бағдардағы саясаткерлер араб елдері үшін бірден бір тұрақты даму жолы мұсылмандық өмір салтын ұстану деп көрсетті. Бұл тұжырымдамалар ішінде ислам социализмі, ислам экономикасы, ислам мемлекеті ұғымдары дәстүрлі ислам құндылықтарын заманауи мемлекеттік қағидаларды нақты елдің ерекшелігімен үндестіріп, саяси және әлеуметтік-экономикалық жағдайды модернизациялауды ұсынды. Яғни, бұл мақалада қазіргі ислам әлеміндегі елдердегі дін мен мемлекеттің арақатынасын зерттегенде нақты жағдайды есепке алып, жүйелі талдау.

Түйін сөздер: Ислам, саясат, дін, мемлекет, қатынастар.

$$
\begin{gathered}
\text { Мейрбаев Б.Б., }{ }^{*} \text { Жорабек Ж. } \\
\text { Казахский национальный университет имени аль-Фараби, Казахстан, г. Алматы } \\
\text { "e-mail: 00077-94@mail.ru }
\end{gathered}
$$

Рекигия и политика в исламском мире

Основной платформой, объединяющей исламские страны мира на религиозной основе, является ислам. Часто говорят о важности исламских ценностей Аля мусульманского мира, Аля того чтобы культивировать Ауховную культуру и общественно-политическую жизнь мусульманских стран. Светские и религиозно-ориентированные политики, возродившие традицию ранних исламских, показали, что единственный путь Аля арабского мира - следовать мусульманскому образу жизни. Среди этих концепций исламского социализма, исламской экономики и исламского государства предполагают, что традиционные исламские ценности будут соответствовать современному состоянию страны и модернизировать политическую и социально-экономическую ситуацию. То есть эта статья представляет собой систематический анализ с учетом реальной ситуации при изучении отношений межАу религией и госуАарством в современном исламском мире.

Ключевые слова: ислам, политика, религия, государство, взаимоотношения. 


\section{Introduction}

The main platform that unites Islamic world nations on a religious basis is Islam. It is often said about the importance of Islamic values for the development of the spiritual culture and social political life of Muslim countries of the Muslim world in search of ways of cultural prosperity and ideological integration of Muslims of the world. Studying the spiritual heritage of the Muslim world requires studying the cultures of different nations, philosophical thought, and understanding the spiritual activities and spiritual world of the Muslim emancipation. In the 50-70's of the 20th century, the concept of the Islamic State in the Arab world required a relationship between secularism and religious power in the context of the modern-day Islamic society.

\section{Main part}

In the Arab world in the $60 \mathrm{~s}$ of the twentieth century, radically new issues were raised regarding the choice of the path of socio-economic and political development. For Arab-Muslim countries, the concept of seeking the third way, which is different from capitalist and socialist structures, has emerged. Secular and religious oriented politicians, who revived the tradition of the early Islamic tradition, have shown that the only way for the Arab world to follow a Muslim lifestyle. Among these concepts, the concepts of Islamic sociolism, Islamic economy and the Islamic state have suggested that traditional Islamic values be up-to-date with the specific state of the country and modernize the political and socioeconomic situation $[1,22 \mathrm{p}]$.

In the middle of the twentieth century, Islamic politicalism in the Arab world was characterized by an inseparable nature. Islamic socialism offers traditional use of traditional Islamic values to the interests of the society, in harmony with the democratic principles of the West. At the beginning of the twentieth century, the joint struggle for the cooperation of Muslim countries, especially the Arab countries, led to the emergence of united international organizations on a religious basis. The formation of organizations that unite the Arab world on political, economic and cultural grounds has been widely promoted in the first half of the 20th century. In 1926 Abdel Aziz invited Mecca to the Muslim congress of Islamic countries.

This year, scientists from Al-Azhar University held a Muslim forum in Cairo. In 1951, the Congress of the Islamic World was held in Karachi, attended by representatives of 32 countries. In 1954, the Islamic Conference was established on the initiative of Saudi Arabia, Egypt and Pakistan. In 1958-1988, Nuri al-Saeed sought to unite Palestine, Jordan, Iraq, Lebanon, and Syria. Anwar Saddam wished to create a large alliance of Syrian states, including Lebanon, Syria, Palestine, Iraq, and Jordan. In 1962, the Islamic World League was established in Mecca. At present this organization is a member of UNESCO and UNESF.

In 1969 the Organization of Islamic Cooperation was established. The Organization of Islamic Cooperation unites 57 states on four continents. The OIC is not a religious organization; it is a member of the Organization's political system, based on Sharia and secular states. OIC countries - observing countries also have different religions. The purpose and mission of this organization is to increase economic well-being of the countries of Islamic civilization and to enhance their political reputation in the field of education and science, to deepen socio-economic cooperation between the members of the organization and to overcome lagging. League of Arab States, a political organization that unites Arab world countries, was established in 1945. The founders of the organization are Egypt, Syria, TransJordania, Iraq, Lebanon and Saudi Arabia. The main convergence of members of this organization, which unites 22 countries, is the Arabic language, the religion of Islam, the paramount principle and the common destiny.

Islam and Shariah standards constitute a system of religious rites and religious values in these countries. In countries other than Lebanon, Islam has been declared a state religion. Looking back on the history of these countries, the struggle for the Arab alliance after the First World War in the Arab world of the Ottoman Empire triggered the Arab nations' struggle to liberate the nation in a new historical context. The Awakening of the national consciousness of the Arab peoples has led to the creation of an organization that is engaged in the Arab nationalism, language, religion, and unity of common people. The Arab nationalists set out to seize the dominance of England and France, which had the mandate to administer this territory, and attempted to concentrate on genuine independence of one of the indigenous Arab peoples for political, economic, and cultural co-operation. The issue of Arab unity in the last quarter of the nineteenth century, the need to unite in the unitary theocratic state was defined in the concept of panIslamism $[2,14 \mathrm{p}]$.

Based on this concept, the priority was given to the role of Islamic religion in the social life of 
the Muslim world. The idea of Islamic unity was consistently reflected in the work of Jamaladdin alAghani and Mohammed Abdo. They have identified Islam as one of the only ideological foundations that unites Muslims against hostile colonialist nations. The politicians in this respect paid special attention to religionism in relation to nationalism and religion. In 1928, Hassan al-Bann was established in Egypt by the Muslim Brotherhood. The Muslim Brotherhood announced the achievement of the Arab League as an important step towards achieving Muslim solidarity and raised the slogan "Allah is the Purpose, the Prophet - Leader, the Quran - The Constitution». Seid Qutub, the great ideologue of Muslim Brotherhood, considered the concept of Muslim nation and Muslim Ummah on a single basis.

Considering that nationalism, racism, and other ideologies are harmful to humanity, he states that all social issues are solved only on the basis of the Qur'an, in the book Social Justice in Islam. In 1951, Mohammed al-Ghazali believed that Islam should rescue mankind from the overthrow of communism and capitalism. Ghazali called his teaching «Islamic Socialism». Islamic socialism should be based on the Taoist and the human brotherhood. The views of the public and political figures in the Muslim East were influenced by the ideological principles of Muslim reformers. However, the introduction of the western secularization process in the Muslim community of the twentieth century and the weakness of the organization and the weakness of the social barrier hindered the creation of these ideas.

Although the official Arabic language of the Arabian countries is Arabian, the economic wellbeing, political system, demography and national composition of the League of Arab States, which unites Arab countries in politics, economy, and culture, have their own dialects. The supreme body of the League of Arab States is the League Council. In 1968 the League Council established the Arab Human Rights Commission. In 2004, the League countries adopted the Arab Charter on Human Rights and the Charter became effective in 2008. In the Arab world, Islam has been declared a state religion. Shari'ah is a legitimate basis for the lives of these societies and human beings. In February 2011, the League of Arab States halted Libya's participation in the organization. The former. The leadership of Kadafi led to the brutal punishment of the people's peaceful rally, which led to the adoption of this decision.

The proposal to close the Libyan air space in March 2011 was unanimously supported by the members of the organization. In November 2011, the organization ceased its presence in Syria. In Syria, the Alauite group holds the country. According to Western sources, the Syrian government is helping Iran. The tension in Syria seems to be religious. Sunni groups support the opposition forces against Bashar al-Assad. The Alauites, the Druze, and the Christians support the government. The conflict in Syria can also have a negative impact on border nations.

In October 2012, artillery shells fired from the territory of Syria were blown up in Akçakal district in southeast Turkey, killing 5 people and wounding 13 . At present, various political and religious groups are active in Syria. Among the Arab countries, the most recognized confessional country is the Republic of Lebanon. The model of confessionalism in Lebanon is aimed at providing equal access to the supreme power for all confessions in the country. According to the country's law, the country's president is Christian-Maronit, prime minister is a Sunni Muslim, and parliament speaker is Shiite Muslim. The government consists of Muslims and Christians on an equal footing. The country's parliament consists of 128 members. The confessional division of parliament members is as follows: 64 Muslims (27 Sunni, 27 Shiites), 8 Druze, 2 Alautites, 64 Christians (32 Maronites, 20 Armenian Apostolic Church, 2 Armenian Catholic Church, 7 Greek Orthodox Churches, 1 Greek Catholic Church, 1 Protestant Sunni, Shiite, Christian and Druze parties, who are taking part in the election campaign, are fighting for a pre-determined confessional quota.

In the history of the Lebanese state, civil war broke out due to several inter-religious clashes. In 1958, a disagreement between Christian and Muslim communities led to civil war. In order to stabilize the situation, the US Army entered the country. Religious confrontation led to the emergence of a conflict between Muslims and Christians in Lebanon in 1975. As a result of the signing of the Taif Agreement in 1990, bloodshed in the country was suspended. More than 150,000 civilians were killed in religious conflicts. The Syrian army, which entered the country in 1976 at the request of the Lebanese government, operated until 2006. In 1978, the Izrus Defense Force, which conquered the southern Lebanese territory, was deported in 2000. At present, the tensions around Syria can have a profound impact on the religious situation in Lebanon. Islamic Republic of Mauritania, Islamic Republic of Pakistan, Islamic Republic of Afghanistan, Islamic Republic of Iran [3, 140 p].

Islamic Republic of Iran in Persian and Shi'a. Also, most of the Shiites are Iraq, Azerbaijan, 
Bahrain. It is well-known that in the Safavids, Ismail Shah took Shiism as a state ideology in Iran in 1501. In the twentieth century, Shah Pehlevi led the Iranian lifestyle. The Islamic Revolution of 1979 destroyed the shah rule and set up a theocratic authority system. The country's spiritual leader is Ayatollah, and the president is the executive power. Twelve members of the Security Council's Guard watchdog monitor the compliance with laws, laws, and Islamic law and ethics. The 86-member council of experts is elected by the supreme leader (head of state). The Council of Experts will hold a closed session. Members of the Council of Experts shall be elected for a term of 8 years by universal voting. Until 1979, Iran became a reliable partner in the West, especially in the United States. Iran has received military and economic assistance from Western Europe and the United States. According to the country's constitution, Christianity, Judaism and Zoroastrianism are recognized and convened in the Majilis.

Non-Muslims are forbidden to hold senior positions. In 1980-1988, Arab-language and Persianspeaking Muslims suffered severe consequences due to the Iraq-Iran war. In the Arab world, various conflicts arise because of weak political, religious, tribal relationships and lack of real partnership. The 1990 Iraq-Kuwait conflict and the 2010 Arab Spring event, the bloodshed in Libya in 2011 and the ongoing conflict in Syria, have revealed that there are still problems in the Arab world. War in the Persian Gulf in 1990-1991 once again proves the war in the Arab world. Saudi Arabia, Egypt, Syria, and Morocco established the Iraqi coalition, while Jordan, Yemen, and Libya stood firm. The US-led NATO-led war in Iraq in 2003 proved that there is no brotherhood and solidarity in the Arab world.

At the Summit of Heads of the Arab States in Damascus in 2008, the Leader of the Libyan Revolution wanted to unite the Arab leaders in order to establish a regional union. Muammar Kadafi suggested introducing the common currency for the countries of the region - dinar. Kadafi said the disagreement between the Arab states is the root cause of the weakness of the Arab world. The author of the Green Book 1970, Kadafi, has been in power since 1969 until October 2011. At Kadafi, a special attention was paid to the social sphere in Libya. Kadafi carried out political reform in the country and purified the country from the leftist and communist ideology. In his third theory, capitalism was a manifestation of opposing humanity, communism as a rebellion against God, and the third way - a path of the evil.
The major geopolitical project, called Africancontinental United Arab Emirates, was based on the idea of panarmenianism. The escalation of the political and economic situation in the Arab world today, the lack of civil society, the discrepancy between power and population, unemployment in youth, unemployment, poverty, food shortages and rise in prices, lack of shelter, lack of opportunities to create a family, and corruption. American political scientist Gary Fuller believes that "the youth group is prone to revolution". In his book The Revolution and Revolt in the Modern World, Jack Goldstone points out that the revolutionary age of the twentieth century will be in developing countries and countries with high demographic growth.

The monarchy in the region (Saudi Arabia, Bahrain, Kuwait, Jordan) began to actively finance social projects in its own countries after the situation in Tunisia and Egypt. Thus, successfully prevented possible social tensions in the country. The defeat of three radical Islamic parties, which participated in one block in the Parliament elections in Algeria in May 2012, shows that the loss of religious fanatics and radicals has already begun. The former competition between Sunni Egypt, Saudi Arabia and Shiite Iran, which seeks leadership in the region, has begun to emerge from a new perspective on Iran's national nuclear program. Islam in the Arab world has been clearly manifested in the culture and traditions of the people. Arab Spring was a major factor in the rise of Islamic political forces in Egypt and Libya. In Egypt's 2011 parliamentary elections, Muslim Brotherhood has won over 40 percent of the vote $[4,75 \mathrm{p}]$.

In many countries, the Muslim Brotherhood, which is an extremist organization, refuses to take up arms and seeks to achieve peace by peaceful means. In the second round of the presidential election in 2012, Mohammed Morsi, a representative of the Muslim Brotherhood, dominated by former Prime Minister Ahmet Shafik, won 52 percent of the vote. In the transitional period, Egyptian authorities were at the Supreme Council of the country's military forces. The political situation and instability in the country also affected interreligious relations. The Coptic Church, which accounts for about 10 percent of the country's population, has collapsed and clashes broke out between many Christians and Muslims. Islam in the Islamic Republic of Pakistan is a state religion. Under the jurisdiction of General Zia ul-Haq, the federal Shari'ah court has made a decision that the laws of the country are in line with Islamic law and values. In Pakistan, religious groups have taken on a mechanism to influence the political 
power. There are often conflicts between Sunnis and Shiites, Sunnis and Ahmadi in this country.

88 percent of the population of Indonesia, the largest Muslim population, is Sunni Muslim, 8.7 percent is Christian, 2 percent is Hinduism, and 1 percent is Buddhist.

In 2011, a Sunni-Shiite religious council was set up in Jakarta. The activities of the council are aimed at strengthening the agreement between Sunnis and Shiite. In Islam, Islam is considered a state religion. In the Constitution of the country, all males are Muslims of an ethnic origin. Religious freedom is declared in the country. 61 percent of the country's population is Muslim, about 20 percent are Buddhists, 9 percent follow Christianity, and 6 percent follow Hinduism. Turkey is a secular state. After the establishment of the Turkish Republic in 1923, the caliphate was dissolved in March 1924 and the Sultanate was abolished. The Ministry of Shariah and Waqif Affairs has been abolished. An article about the state religion of Islam in the Constitution was deleted. Temples (boats) were distributed. Aia Sofia mosque has become a museum. Imams were banned from participating in politics. There is also a special department to monitor religious organizations and mosques. The Department has the authority to designate imams and muftis in the country.

In 1926, instead of the Hijra calendar, the Gregorian calendar was adopted. Bananas were banned for women, and many women were banned from being legally allowed. In 1928 the Latin alphabet was adopted in the country. The principle of disarmament, founded by Mustafa Kemal Atatürk (1881-1938), proclaims the principle of republicanism, nationalism, nationalism, statehood, lyism (the system of secular state formation). During the rule of Kemal, the Quran was translated into Turkish. In 1924, a religious affairs office was set up in Turkey to solve the problems of faith, worship and morals of Muslims in the country. At present, the clergy are financed by the state, and about 120 thousand people are employed in the country. In 2010, reform of the religious service system of Turkey was carried out. According to the reform, issues of religious activity, religious education, religious publishing, religious preaching were systematized. The Mosque has special training courses for preachers. Religious education is aimed at providing spiritual and material assistance to children, women and prisoners, disabled people.

Wife preaching focuses on bringing up a family and a child. More than 80 thousand mosques are registered in the country. There are about 40 branches of theology (religious studies) in Turkish universities. There are also 500 imams-lads. Speaking at the World Islamic Economic Forum in June 2011, the President emphasized that Islam should build a positive image of charity and peace, justice as a religion. He also pointed out that the Muslim world needs a modernization process for technological, scientific and economic development. The relationship between religion and politics in the Islamic world is based on the people's tradition and tradition. Therefore, when studying the relation between religion and state in the countries of the Islamic world, it requires a systematic analysis, taking into account the actual situation.

\section{Conclusion}

It is important to keep in mind the benefits that have been preserved up to now in the past on the basis of the ancient, effective, profitable aspects of the indigenous religious beliefs. This is because the beliefs that have been shaped, systematised, sorted out, disadvantaged, positive and negative sides of the nation are a real manifestation of the true and natural national identity of our people. We must consider its worldview and practical aspects.

Modern civilization needs to be beyond the demands. The civilization that all human beings have to offer must support and re-support Islam and to convey the beliefs and feelings of Islam. There is a need for a variant of positive civilizational demands and values that recognizes and uses all the spiritual, economic, political, social, and even domestic aspects of the values.

The religion should provide content so that religious radicals do not recognize or deny any of the current points. That's why the error and confusion are starting with those negative ideas and fanaticism, so this version should be designed so that its principles are explicitly explicitly denied and protected from the standpoint of their principles. At the same time, at a certain level, the methodological and theoretical aspects of how to deal with them must be very strong $[6,44 \mathrm{p}]$.

The Quran, Hadiths and other Muslim religious texts should be avoided, allowing them to accept only one positive prism. Some Hermeneutics argue that the text is understood only as the general raw material object depends on the level of knowledge and self-awareness of the interpreter. In fact, these texts are too old, sometimes too general, and allow for different interpretations. Here's how radical alien currents are easily used and driven to fit their goals. Therefore, the national version of Islam must 
be based on genuine, optimistic, effective, secular interpretation and guiding it.

Islamic philosophy and ideology should be distinguished from reality. Some aspects of philosophy are focused on expanding the scope of the worldview and reflection that do not apply in practice. For example, Sufism is the ideal of the spiritual ideal of humanity and the love of God, the eternal love of God, the sublime life style. In this regard, it is also lawful to ask, «How to live?» This question is clearly described in J. Balasaguni's poem «The Blessing of Knowledge»: Through the debate of Omermish and Ogldilmis, an alternative choice of the secular and secular lifestyle varies and presents itself as an eternal definition of the future generations. Sufism is also supported by the philosophy of religion, but it is not a fanatic society, because it is a fanatic one.

However, it should not be forgotten that it is not an exception but a generalized exodus that has been assigned to some distinguished people. It should not contradict political, social, cultural, economic, spiritual-legal strategies and tactics of the country, and should, as far as possible, support it. At the same time, it should be neutral in today's Islamic countries, without interfering with religious-related conflicts and conflicts.It is important to keep in mind that the principle of «believing in the religion is personality» «no violence in religion» should be kept in mind, not only in theory, but also in practice [7, 44-45 p].

Islam should be guided not only by its worship but also by its ideological, scientific, educational and ethical considerations. The person in our society should be prepared not to be influenced by feelings of power and faith but who will solve the issue in a wise, secular, intellectual way. It is obvious that we do not need the fate of Muslim states, which have become «the battlefield of modern times». Hence, in the middle Ages, the Arab-Muslim Renaissance era is the most prominent of Islamic thought in the Turkic thinkers. As our faith in Islam becomes stronger, we need to focus on increasing the secular and intellectual power so that we can prepare the «Al-Farabi» today. The direct involvement in the strategy of creating an intellectual nation requires attention to the educational side of Islam. That is to say, Islam should not be regarded as a pure religion, but a model that calls for knowledge and wisdom, wisdom and humanity, and finally ultimately comes to the principle of «intellectual nation».

\section{References}

1 Abzhalov S. U. Hanafi mazhaby ilimdyk erekshelikteri. - KazNU xabarshisi, 2013. - 22 p.

2 Adilbaev A. // Hanafi gilimdarinin islam fikhna katisty negizgi enbekteri // Islamtanu zhane arab filosofiasi maseleleri - Almaty, 2008. -14 p.

3 Baitenova N., Zatov K., Risbekova Sh., Borbasova., Beisenov B., Meirbayev B., Kurmanalieva A. Kazirgi Kazakhstandagi zhana dini agimdar. - A.: Kazakh university, 2010. -140 p

4 Baitenova N., Zatov K., Risbekova Sh., Borbasova., Beisenov B., Meirbayev B., Kurmanalieva A. Kazirgi Kazakhstandagi zhana dini agimdar. - A.: Kazakh university, 2010. -75 p

5 Adilbaev A. // Hanafi gilimdarinin islam fikhna katisty negizgi enbekteri // Islamtanu zhane arab filosofiasi maseleleri - Almaty, 2008. - 96 p.

6 Baitenova N., Zatov K., Risbekova Sh., Borbasova., Beisenov B., Meirbayev B., Kurmanalieva A. Kazirgi dasturden tis dini adimdar men kul'tter. - A.: Kazakh university, 2013. - 44 p

7 Abzhalov S. U. Hanafi mazhaby ilimdyk erekshelikteri. - KazNU xabarshisi, 2013. - 44-45 p. 